\title{
The Market Distortion Effect of Government Intervention in Higher Education
}

\author{
Jezyl C. Cutamora
}

Cebu Normal University, Cebu City, Philippines,

https://orcid.org/0000-0003-3227-4543

Email Correspondence: cutamoraj@cnu.edu.ph

\begin{abstract}
In the Philippines, a mixture of public and private higher education institutions (HEIs) exists. Because of the government subsidy among the public HEls, the major concern of the private sector is the "uneven playing field". This study hopes to eliminate this unhealthy competition and market distortion in the educational landscape. This study utilizes the quantitative non-experimental retrospective explanatory design. Results show that regardless of the extent of state intervention, the market can be distorted. Hence, assigning specific programs to be offered based on the type of HEl is a good alternative. The programs to be fully subsidized and offered by the government are agriculture, sciences, engineering, manufacturing and construction, and humanities and arts (HA) while services, health and welfare, education and social sciences, business and law programs will be for private sector service providers. This stimulates healthy competition among the HEls leading to a better quality of education.
\end{abstract}

Keywords: higher education, government subsidy, government intervention, public HEls, private HEls, market distortion

\subsection{Introduction}

Although tertiary education is sometimes viewed as a government function, it may also be viewed otherwise. In most countries of the world like the Unites States, Great Britain, France, Japan, including the Philippines, a mix of public and private higher education institutions (HEls) exists. In the Philippines, there is Republic Act 10931 that is also known as the Universal Access to Quality Tertiary Education Act. It is a Philippine law that institutionalizes free tuition and exemption from other fees in state universities and colleges (SUCs), local universities and colleges (LUCs) in the country (Unified Student Financial Assistance System for Tertiary Education, n.d.).
Because of the co-existence of public and private HEls and of the subsidy of the government in the public service providers, the governmentfunded ones are viewed as competitors by the private HEls. This subsidy or government intervention therefore distorts the market in the academe with public and private HEls as key economic players. According to Puno (n.d.), the competition, however, is not the type that enhances quality but a competition that is labeled as unfair because the "playing field is not even". He further mentioned the need to make public service more private and for the private sector to be more public. However, since a higher education market framework for a mix of public- 
private sector players is non-existent, a way to rationalize the market operatives has not been defined.

TheEconomicHigherEducation Rationalization Framework (EHER) is an essential input for higher education policy. The 21st century has seen a tremendous expansion of higher education globally. In Southeast Asia, East Asia, and the Pacific, higher education enrollment rose twelvefold from 1970 to 2007 (from 3.9 M in 1970 to 46.7 $M$ in 2007) as noted by the Asian Development Bank [ADB] (2012). No substantial increase in government support for higher education has been pointed out despite the huge enrollment increase. In the Philippines, public expenditure for higher education was only $0.273 \%$ of the GDP in 2009 (Department of Budget and Management, 2016) compared to the $2 \%$ expenditure in more developed economies (Altbach et al., 2009). The magnitude of public spending on higher education reflects the philosophical stance of government leaders. Those who believe that higher education is a public good will invest more, while those who do not will invest less.

When the government fails to substantially invest in higher education amidst strong demand for the service, the vacuum will be filled in by the private sector. Underinvestment in public higher education adversely affects quality in state-funded higher education institutions. This quality, nonetheless, becomes the equilibrium quality target for most of the private sector service providers. Consequently, the overall quality of higher education becomes less than satisfactory for both the government and the international community (Shaw, 2010).

An economic higher education rationalization framework that stimulates healthy competition among the economic players raises the overall equilibrium quality condition of the services. For this reason, the development of such a framework is urgently needed in the Philippines when the country is poised to join the much broader ASEAN economies.

This study hopes to develop a cost-effective higher education rationalization framework that optimizes overall quality. Specifically, it determines the various higher education programs to be fully subsidized by the state and which should be left to the private sector service providers.

This study utilizes the data on the marginal rate of returns (to the economy) of the various higher education programs by Cutamora and Padua (2020), that determined the higher education programs which should be fully subsidized by the government and the programs that should belong to the private sector (Cutamora \& Padua, 2020). This study evaluates the suggested paradigm with an economic evaluation model to determine its effect in the higher education market. The phenomenon of distortion in the higher education market has been explored, and an allocation that eliminates market distortion is proposed.

Classical economics has established that any form of government intervention, in an otherwise perfectly competitive market environment, brings about market distortions (Smith, n.d.). Market distortion is often manifested in the form of price alteration from the path of price equilibrium. More succinctly, private higher education institutions set their price at a specific bracket, and find that there are only a few takers of the programs. Iteratively, these institutions lower their costs until they reach an equilibrium price which maximizes the number of program takers. When the government intervenes by establishing government-funded higher education institutions, the equilibrium price becomes lower, forcing the private higher education institutions to live within their means. The lowering of the equilibrium price impacts adversely on the overall quality of higher education of the country. 
This study therefore aims to determine the educational programs that should be offered or assigned to be offered to either public or private HEls. This initiative can eliminate the unhealthy competition between the private and the public HEls. Furthermore, this can help minimize the market distortion effect brought about by the government subsidy.

\subsection{Methodology}

This study utilized the quantitative nonexperimental retrospective explanatory design and data mining techniques. Data mining techniques were used to determine the patterns that emerge out of the data plots of GDP versus the percentage of graduates per higher education program (Cutamora \& Padua, 2020). Furthermore, data mining results on the marginal rate of returns (to the economy) of the various higher education programs were used in determining which higher education programs should be fully subsidized by the government and which of the programs should be catered to by the private sector.

The researcher focused the analysis on selected Asian economies with more or less similar situations: developing or underdeveloped economies, the participation of the private sector in higher education, and democratic societies. Data from eighteen (18) Asian economies on their 2014 higher education programs were obtained from reliable internet sources (United Nations Educational, Scientific and Cultural Organization [UNESCO], Institute for Statistics, 2012). The number of graduates who joined the countries' labor force within the year and contributed to the Gross Domestic Product (GDP) was thoroughly compiled in a reliable internet database (International Monetary Fund [IMF], 2015). From the list of all Asian countries, only those with complete information on their 2014 percentage of graduates per program and 2015 GDP for a total of eighteen (18) countries (roughly $40 \%$ of all Asian countries) were included.
These countries were Azerbaijan, Japan, Lao People's Democratic Republic, Malaysia, Mongolia, Nepal, Philippines, Sri Lanka, Vietnam, Indonesia, Afghanistan, Armenia, India, Bangladesh, Georgia, Bhutan, Kyrgyzstan, and Kazakhstan.

The higher education courses were clustered into eight (8) programs based on the 2011 International Standard Classification of Education or ISCED (UNESCO, Institute of Statistics, 2012). The inter- or multi-disciplinary programs were classified according to a majority rule (in the field in which students spent most of their time). These are agriculture $(\mathrm{Ag})$, education (Ed), engineering, manufacturing and construction (Eng), health and welfare $(\mathrm{HW})$, humanities and arts $(\mathrm{HA})$, sciences (Sci), services (Serv), and social sciences, business, and law (SocSci).

In the data analysis, the market distortion model was utilized. The traditional definition of market distortion requires knowledge of prices. Thus, to assess the extent of market distortion, one needs to know the general components of production cost per capita and the profit component. Data on profits derived by higher education institutions are challenging, if not impossible, to obtain. For this reason, the researcher proposed an alternative model to gauge the extent of market distortion, which does not require knowledge of the abovementioned economic parameters.

In a perfectly competitive environment, each player has an equal chance of surviving and succeeding in their respective economic goals. This was mathematically expressed by assuming a uniform distribution on the probabilities of success of the higher education institutions. Let $X$ be the probability of success and $\pi$ as constant, then:

\section{Perfectly Competitive Model:}

$$
\pi(\mathrm{X})=1, \quad 0<\mathrm{X}<1
$$

State intervention was then introduced in Model (1) in a mixture model. Let $\varepsilon>0$ be the extent of state intervention, which can be anywhere from 
$0 \%$ to $100 \%$. Let $\mathrm{X}$ be the probability of success, $\pi$ as constant, $\varepsilon$ as the extent of state intervention and $\beta$ as the beta value. The State-intervention model is, then, given by:

\section{State Intervention Model:}

$$
\mathrm{f}(\mathrm{X})=(1-\varepsilon) \pi(\mathrm{X})+\varepsilon \beta(\mathrm{X})
$$

where $\beta(\mathrm{X})$ is a beta distribution defined by:

$$
\beta(x)=\frac{1}{\beta(\alpha, \beta)} X^{\alpha-1}(1-X)^{\beta-1}
$$

When $\alpha=1, \beta=1$, Equation (3) reduces to a uniform distribution i.e., the government intervenes but sets the price at the same level as the private higher education institutions.

When $\varepsilon=0$, Model (2) says that there is no government intervention; when $\varepsilon=0.10$, Model (2) states that there is $10 \%$ state intervention in the market, and so on.

When Model (2) is plotted against the model (1), we have a clear picture of the extent to which deviation from a $0.45^{\circ}$ straight line is evident when $\varepsilon=0$ :

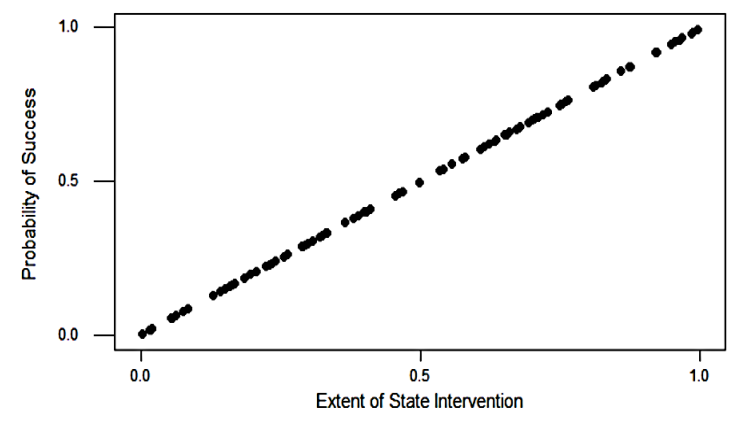

Figure 1. Probability of Success vs. Extent of State Intervention

The graph looks like this (see figure1) when there is no state intervention, $\varepsilon=0$. The slope $\underline{\mathbf{b}}$ of the line $b=1$, and $R^{2}=100 \%$ ( $R$ squared value). When $\varepsilon$ or extent of intervention is increased, the following graphs Figures 2-4 will manifest deviations from the line:
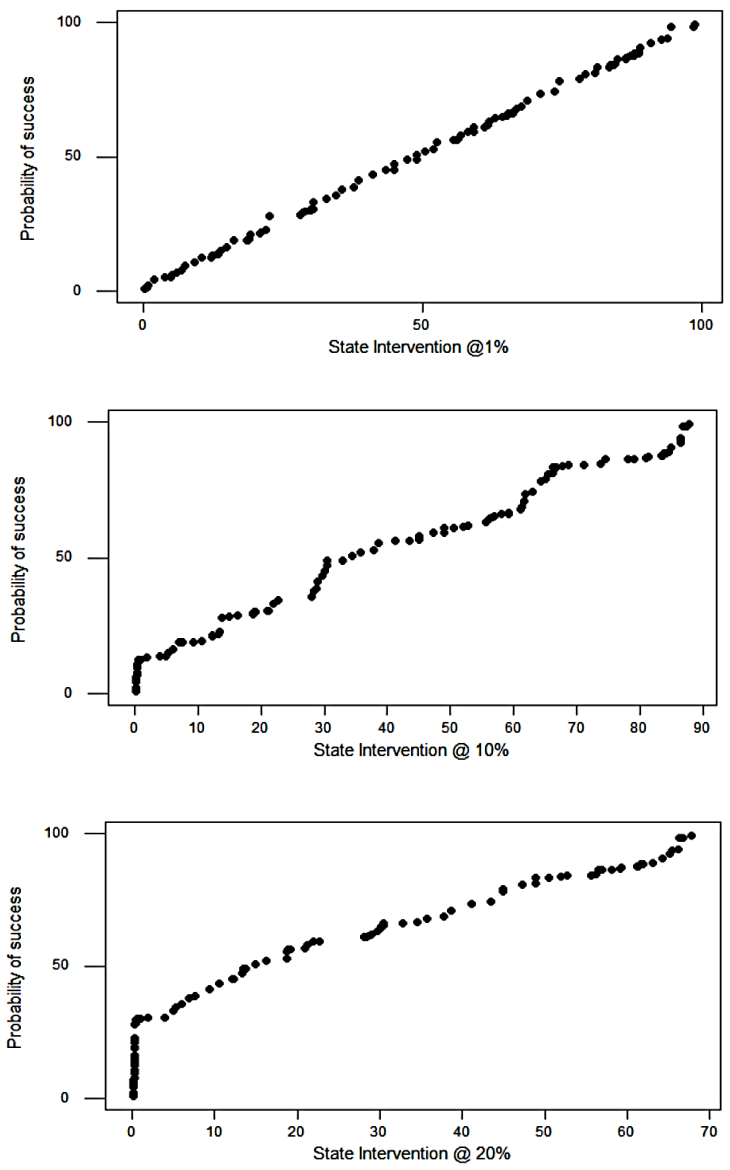

Figure 2-4. Probability of success vs. State Intervention at $1 \%, 10 \%, 20 \%$

Distortion measure can now be defined as:

\section{Market Distortion Measure (MDM):}

In model (2), for a given $\varepsilon=0$, the market distortion measure is:

$$
\mathrm{MDM}=100 \%-\mathrm{R}^{2} \times 100 \%
$$

Model (4) measures the departure of the graph from a perfectly straight line. A chart between the distortion measures MDM versus the extent of intervention $(\varepsilon)$ is an excellent way to determine how much distortion will be introduced into the system given an intervention $(\varepsilon)$. 


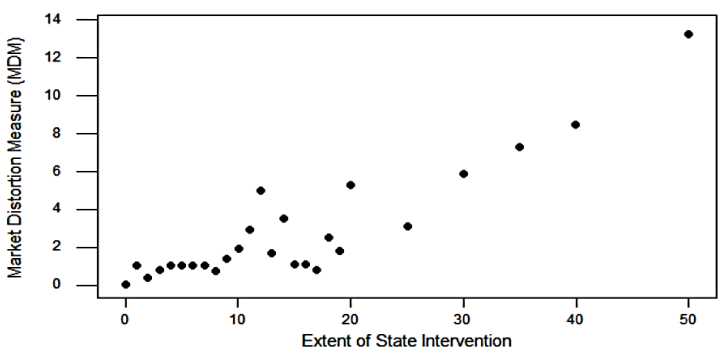

Figure 5. MDM vs. Extent of State Intervention

The graphical picture shows that no matter how small the intervention is, distortions will be expected, confirming the classical economics theory. However, there is a range of interventions that minimizes distortion. With this consequence, an allocation that eliminates market distortion is now proposed.

\subsection{Results and Discussion}

The researcher started by evaluating how much distortion in the higher education market can be introduced when the government interferes, and it was found out that regardless of the extent of state intervention, the market can be distorted. Hence, this section proposes an alternative scheme that removes market distortion.

Taking into account the average rank of the marginal rate of returns, the ideal cost per program (Department of Budget and Management and CHED, 2004), and the program weight (based on CHED's normative funding criteria), the researcher determine which of the various higher education programs should be fully subsidized by the government and which should be given to the private sector service providers. The priority cost weight is an index that indicates how much more expensive it is to offer each program/ discipline relative to the BS Education program. For instance, if a specific program has a cost weight of 1.5 , it means that said program is $50 \%$ more costly to provide than the BS Education program. Priority weights reflect the relative importance of various programs in promoting national development objectives. Under the formula, undergraduate enrolment in the following fields is assigned a priority weight of 1.25: natural science mathematics, engineering, IT-related disciplines, and agriculture. These disciplines are considered high-priority disciplines because they are given the highest priority weights. In contrast, undergraduate enrolment in the following fields is set a priority weight of 0.75 : business administration and related domains, law and jurisprudence, and medical and allied sciences. These disciplines may be considered low-priority fields because they are given the lowest priority weights. On the other hand, undergraduate enrolment in the remaining disciplines is assigned a priority weight of 1 . Thus, these disciplines may be considered as medium priority disciplines Cutamora \& Padua, 2020.

Table 1 presents the ranking of the program as the basis for the recommendation.

The top four (4) programs with the direct link to national productivity which will be fully subsidized and offered by the State are agriculture (Ag), sciences (Sci), engineering, manufacturing and construction (Eng) and humanities and arts (Hum) while services (Serv), health and welfare (HW), education(Ed) and social sciences (SocSci), business and law programs will be for the private sector service providers. This result is supported by an article in The Economist stating that private institutions tend to supply more courses such as law and accountancy ("Excelence vs. Equity", 2015). As measured through COE/COD grant status CHED (2014) identified that most public HEls are good at courses on agriculture and sciences while private HEls at courses such as services; health and medical-related courses; social sciences, business, and law; education and engineering. 
Unbundling of higher education services eliminates both market distortion and unfair competition between public and private HEls. In effect, it stimulates healthy competition among public economic players and among private ones, which can ultimately augment the quality condition of the higher education services being delivered.

Table 1. Mean Ranking of the Higher Education Programs

\begin{tabular}{|c|c|c|c|c|c|}
\hline Program & $\begin{array}{l}\text { MRR Rank } \\
\text { (based on } \\
\text { Cutamora and } \\
\text { Padua, 2020) }\end{array}$ & $\begin{array}{l}\text { Program } \\
\text { cost Rank } \\
(C H E D)\end{array}$ & $\begin{array}{c}\text { Program } \\
\text { weight } \\
\text { Rank (CHED) }\end{array}$ & $\begin{array}{l}\text { Average } \\
\text { Rank }\end{array}$ & Implication \\
\hline Agriculture (Ag) & 1 & 3 & 1 & 1.7 & PUBLIC \\
\hline Services (Serv) & 2 & 6 & 2 & 3.33 & PRIVATE \\
\hline $\begin{array}{l}\text { Humanities and } \\
\text { Arts }(H A)\end{array}$ & 3 & 4 & 2 & 3 & PUBLIC \\
\hline Sciences (Sci) & 4 & 1 & 1 & 2 & PUBLIC \\
\hline $\begin{array}{l}\text { Health and } \\
\text { Welfare }(\mathrm{HW})\end{array}$ & 5 & 5 & 3 & 4.33 & PRIVATE \\
\hline $\begin{array}{l}\text { Engineering, } \\
\text { Manufacturing } \\
\text { and Construction } \\
\text { (Eng) }\end{array}$ & 6 & 2 & 1 & 3 & PUBLIC \\
\hline Education $(\mathrm{Ed})$ & 7 & 8 & 2 & 5.67 & PRIVATE \\
\hline $\begin{array}{l}\text { Social Sciences, } \\
\text { Business, and } \\
\text { Law (SocSci) }\end{array}$ & 8 & 7 & 3 & 6 & PRIVATE \\
\hline
\end{tabular}

\section{Financial Feasibility of the Proposed Framework}

This section illustrates the financial sustainability under this rationalized framework for higher education. The table below presents the state investment of the Philippines in the identified SUC programs as of 2014.

Table 2 illustrates the budgetary requirements needed by the public and private HEls annually for the final year of the college students' schooling when this framework is adopted. In particular, the state universities and colleges would require roughly $42 \mathrm{~B}$ pesos to implement the rationalization scheme and support the final schooling of students. Mutatus mutandis, the estimated funding requirement for all students in the four (4) programs at all levels in the SUCS, would run to $170 \mathrm{~B}$ pesos. However, as of 2017 , the General Appropriations Act provided for a total of $58.72 \mathrm{~B}$ pesos for the state universities and colleges to fund the gamut of programs currently offered by these state institutions. According to the Department of Labor and Employment (DOLE) secretary Rosalinda Baldoz, a cursory analysis of these figures would at once reveal a severe underfunding of the state institutions, which could, perhaps, explain the current quality levels exhibited by graduates from these schools ("Mismatch Hounds Labor Market", 2016). Furthermore, Luis Alberto Anastacio, the Conglomerate Servicio Filipino Inc. President and CEO, observed that only $1 \%$ of every thousand applicants are hired by the various industries to join the productive labor force of the country ("Mismatch Hounds Labor Market", 2016). 
Table 2. Summary of Annual Investment per Program in One Year Level

\begin{tabular}{|c|c|c|c|c|c|c|c|}
\hline \multirow[b]{2}{*}{ Program } & \multirow[b]{2}{*}{$\begin{array}{l}\text { No. of } \\
2014 \\
\text { grads }\end{array}$} & \multirow[b]{2}{*}{$\begin{array}{l}\text { Optimal } \\
\text { No. of } \\
\text { Grads }\end{array}$} & \multirow[b]{2}{*}{$\begin{array}{l}\text { Average } \\
\text { Ideal } \\
\text { Price/ } \\
\text { student } \\
\text { (CHED, } \\
\text { 2014) }\end{array}$} & \multirow[b]{2}{*}{$\begin{array}{l}\text { Price } \\
\text { (Ave* } \\
\text { weight) }\end{array}$} & \multirow[b]{2}{*}{$\begin{array}{l}\text { Program } \\
\text { Weight } \\
\text { (CHED, } \\
\text { 2014) }\end{array}$} & \multirow[b]{2}{*}{$\begin{array}{l}=\text { number or } \\
\text { grad2014 x Price }\end{array}$} & \multirow[b]{2}{*}{$\begin{array}{c}\text { Optimal number } \\
\text { x Price }\end{array}$} \\
\hline & & & & & & & \\
\hline \multicolumn{8}{|c|}{ PUBLIC OFFERING } \\
\hline $\begin{array}{l}\text { Agriculture } \\
\text { (Ag) }\end{array}$ & 5509 & 22,641 & $65,703.98$ & 82129.98 & 1.25 & $452,454,032.3$ & 1859504877 \\
\hline Sciences (Sci) & 19977 & 72,706 & 78864.66 & 98580.83 & 1.25 & $1,969,349,141$ & 7167417826 \\
\hline $\begin{array}{l}\text { Engineering, } \\
\text { Manufacturing } \\
\text { and } \\
\text { Construction } \\
\text { (Eng) }\end{array}$ & 32206 & 182,702 & 68597.83 & 85747.29 & 1.25 & $2,761,577,141$ & 15666201378 \\
\hline \multirow{3}{*}{$\begin{array}{l}\text { Humanities } \\
\text { and Arts (HA) }\end{array}$} & 26818 & 241,787 & $72,889.72$ & 72889.72 & 1 & $1,954,756,511$ & 17623786730 \\
\hline & 84,510 & $\begin{array}{r}\mathbf{5 1 9 , 8 3 6} \\
(58.5 \%)\end{array}$ & & & & & \\
\hline & & & & \multicolumn{2}{|c|}{ PUBLIC TOTAL } & $7,138,136,825.00$ & $42,316,910,810.00$ \\
\hline \multicolumn{8}{|c|}{ PRIVATE OFFERING } \\
\hline Services (Serv) & 38805 & 105,214 & $56,864.14$ & 56864.14 & 1 & $2,206,612,953$ & 5982903626 \\
\hline $\begin{array}{l}\text { Health and } \\
\text { Welfare (HW) }\end{array}$ & 4419 & 53,757 & $85,871.50$ & 64403.63 & 0.75 & $284,599,618.9$ & 3462145938 \\
\hline Education (Ed) & 13439 & 52,062 & $45,985.52$ & 45985.52 & 1 & $617,999,403.3$ & 2394098142 \\
\hline \multirow{3}{*}{$\begin{array}{l}\text { Social } \\
\text { Sciences, } \\
\text { Business, and } \\
\text { Law (SocSci) }\end{array}$} & 78941 & 158427 & 62482.13 & 46861.6 & 0.75 & $3,699,301,368$ & 7424142703 \\
\hline & 135,604 & $\begin{array}{r}369,460 \\
(41.5 \%)\end{array}$ & & & & & \\
\hline & & & & \multicolumn{2}{|c|}{ PRIVATE TOTAL } & $6,808,513,343$ & $19,263,290,409.00$ \\
\hline GRAND TOTAL & & & & & & $13,946,650,169$ & $61,580,201,220.00$ \\
\hline
\end{tabular}

Table 3. Higher Education Investment of Selected Countries (Source: UNESCO Institute for Statistics, 2014)

\begin{tabular}{lllll}
\hline Country (billion Php) & Allotted \% for HE & GDP & Investment (billion\$) & Investment \\
\hline Philippines & $\mathbf{0 . 0 0 3 2}$ & $\mathbf{3 0 3 7 . 1}$ & $\mathbf{9 . 7 1 9}$ & $\mathbf{4 3 . 7 3}$ \\
Indonesia & 0.0050 & 3511.4 & 17.557 & $\mathbf{7 9 . 0 1}$ \\
Thailand & 0.0050 & 5611.6 & 28.058 & 126.26 \\
Vietnam & 0.0050 & 2233.0 & 11.165 & 50.24 \\
Singapore & 0.0122 & 53604.2 & 653.971 & $2,942.87$ \\
Malaysia & 0.0210 & 10654.0 & 223.735 & $1,006.81$ \\
\hline
\end{tabular}


Table 3 presents the percentage of GDP allocated specifically for higher education among the selected countries with available data in UNESCO, Institute for Statistics (2014). The underfunding of state-run higher education institutions can be better appreciated than the state investments in selected ASEAN-member nations. Table 3 displays the summary of higher education investments as of 2014. Tabular values show that the Philippines has the least investment in higher education. Moreover, the figures likewise reveal that the current proposal to rationalize the delivery of higher education services would require funding support which is at least three(3) times the current levels or approximately, at the same funding level of the Royal Thai Government for state institutions in 2014. If other Asian countries can afford to invest as much in higher education, there appears to be no reason why the Philippines would be unable to support the needed higher education funding reforms required to elevate the quality of its nation's labor force. A case in point is Vietnam, whose 2014 GDP was only $\$ 2,233 B$, significantly lower than the Philippines' $\$ 3,037.1 B$ for the same year. Despite Vietnam's meager financial resources, it deliberately allocated $0.50 \%$ of its GDP to higher education while the Philippines only allocated $0.32 \%$ of its GDP.

\section{0 Conclusion and Recommendation}

The current higher education scheme proposal eliminated the unnecessary competition and roughness of the academic landscape by assigning specific sets of programs that should be offered by the State institutions alone and other sets of courses for the private HEls. Because the government invested a lot to subsidize the students enrolled in the public HEIS, the top four (4) programs with the direct link to national productivity will be proposed to be fully subsidized and offered by the government. These are agriculture, sciences, engineering, manufacturing and construction and humanities and arts. On the other hand, services, health and welfare, Education and social sciences, business and law programs will be for the private sector service providers. In this scheme, public HEl's will no longer compete with the private ones. Instead, the private schools will compete among themselves, and the market forces will dictate both price and quality in the programs assigned to the industry. This will therefore stimulate a healthy competition which leads to a better quality of education.

\section{References}

Altbach, P., Reisberg, L. \& Rumbley, L. (2009). Trends in global higher education: Tracking an academic revolution: $A$ report prepared for the UNESCO 2009 world conference on higher education. http://www.cep.edu.rs/public/ Altbach,_Reisberg,_Rumbley_Tracking_an_ Academic_Revolution,_UNESCO_2009.pdf

Asian Development Bank [ADB]. (2012). Higher education in dynamic asia: Counting the cost financing asian higher eudcation for inclusive growth [Report No. RPS124448]. https:// www.adb.org/publications/series/highereducation-dynamic-asia-study-reports

Commission on Higher Education [CHED]. (2014). Guidelines for grants and proposals of center of excellence/center of development in Philosophy [CMO No. 3, s2014]. https://ched.gov.ph/wpcontent/uploads/2017/10/CMO-03-2014.pdf

Cutamora, J. C., \& Padua, R. N. (2020). An economic rationalization framework for higher education. Recoletos Multidisciplinary Research Journal, 8(1), 43-65. https://doi. org/10.32871/rmrj2008.01.04 
Department of Budget and Management. (2016). National expenditure program 2016. https:// www.dbm.gov.ph/index.php/budgetdocuments/2016/national-expenditureprogram

Department of Budget and Management, \& Commission on Higher Education [CHED]. (2004). Application of normative funding (NF) in the allocation of expenditures to state universities and colleges (SUCS) starting FY 2005 budget and thereafter [Joint Circular No. 2, s.2004]. https://www.dbm.gov.ph/wpcontent/uploads/2012/03/jc_2004-2_001.pdf

Excellence vs. equity. (2015, March 28). The Economist. https://www.economist.com/ sites/default/files/20150328_sr_univ2.pdf

International Monetary Fund (2015, April). World economic and financial surveys. World Economic Outlook Database: https:// www.imf.org/en/Publications/WEO/weodatabase/2015/April

Mismatch hounds labor market - DOLE. (2016, March 10). The Philippine Star. https://www. philstar.com/business/2016/03/10/1561618/ mismatch-hounds-labor-market-dole

Puno, C. (n.d.). Higher education development strategies in the Philippines for a strong republic. http://www.asia-edu.org/EN/ NewsCenter_View.asp?classid=75\&id=366 \&parentclassid $=$

Shaw, J. S. (2010). Education- a bad public good? The Independent Review: A Journal of Political Economy, 15(2), 241-256. https://www. independent.org/publications/tir/article. asp?id=804
Smith, A. (n.d.) . An inquiry into the nature and causes of the wealth of nations. https://books.google. com.ph/books/about/An_Inquiry_Into_the_ Nature_and_Causes_of.html?id=0lYTWalAQ DYC\&printsec $=$ frontcover\&source $=k p \_r e a d$ button\&redir_esc $=y \# v=$ onepage $\& q \& f=$ false

United Nations Educational, Scientific and Cultural Organization [UNESCO] Institute for Statistics. (2012). International Standard Classification of Education: ISCED 2011. http://uis.unesco.org/ sites/default/files/documents/internationalstandard-classification-of-education-isced2011-en.pdf

United Nations Educational, Scientific and Cultural Organization [UNESCO] Institute for Statistics. (2014). Higher education in Asia: Expanding out, expanding up: The rise of graduate education and university research. http://uis. unesco.org/sites/default/files/documents/ higher-education-in-asia-expanding-outexpanding-up-2014-en.pdf

Unified Student Financial Assistance System for Tertiary Education. (n.d.). Universal Access to Quality Tertiary Education Act. https://unifast. gov.ph/uniqtea.php 